\title{
MONEY AND EXCHANGE RATES IN THE GROSSMAN-WEISS-ROTEMBERG MODEL
}

Fernando Alvarez

Andrew Atkeson

NBER Working Paper 5678

\section{NATIONAL BUREAU OF ECONOMIC RESEARCH 1050 Massachusetts Avenue \\ Cambridge, MA 02138 \\ July 1996}

This paper is part of NBER's research program in International Finance and Macroeconomics. Any opinions expressed are those of the authors and not those of the National Bureau of Economic Research.

(C) 1996 by Fernando Alvarez and Andrew Atkeson. All rights reserved. Short sections of text, not to exceed two paragraphs, may be quoted without explicit permission provided that full credit, including $(\mathcal{O}$ notice, is given to the source. 


\title{
MONEY AND EXCHANGE RATES IN \\ THE GROSSMAN-WEISS-ROTEMBERG \\ MODEL
}

\begin{abstract}
We examine the impact of monetary injections in the Grossman-Weiss-Rotemberg Model. We show that monetary shocks can lead to nominal exchange rates that are much more volatile than inflation, money growth, or interest rate differentials. Moreover, movements in real exchange rates following monetary injections can be persistent and nearly as large as movements in nominal exchange rates.
\end{abstract}

Fernando Alvarez

Department of Economics

University of Chicago

1126 East 59th Street

Chicago, IL 60637
Andrew Atkeson

Department of Economics

University of Pennsylvania

3718 Locust Walk

Philadelphia, PA 19104

and NBER 


\section{Introduction}

Few puzzles in international economics are as perplexing as the behavior of exchange rates. Since the breakdown of the Bretton Woods system of managed exchange rates in the early 1970's, there have been large and persistent movements in the nominal exchange rates between the currencies of the United States, Japan, and the countries of Western Europe. These movements in nominal exchange rates have been much larger than the inflation, money growth, or interest rate differentials across these countries. Moreover, at all but very low frequencies, these movements in nominal exchange rates are associated with movements in real exchange rates of roughly the same size and persistence.

In this paper, we consider whether a model of the impact of monetary injections on asset prices first proposed by Grossman and Weiss (1983) and Rotemberg (1984, 1985) can reproduce these salient features of exchange rate behavior. These authors develop a model in which agents visit the asset market infrequently to obtain currency to finance extend shopping trips in the goods market. This assumption is in the spirit of the inventory-theoretic models of money demand in Baumol (1952) and Tobin (1956) and their general equilibrium counterparts in Jovanovic (1982) and Romer (1986). Agents' visits to the asset market are staggered, so, at any point in time, only a fraction of agents are in the asset market. When interest rates are positive, agents choose not to trade currency for other assets between visits to the asset market since they cannot begin to spend the currency until they return to the asset market to fetch it. Thus, in this model, when the government trades bonds and currency in an open market operation at a point in time, it does so with only the fraction of agents currently visiting 
the asset market. As a result, monetary injections have a disproportionate impact on these agents' currency holdings and consumption and on nominal and real asset prices as well.

The distributional effects in the models in GrossmanWeiss (1983) and Rotemberg $(1984,1985)$ complicate the analysis and effectively limit these studies to one-time unanticipated shocks in deterministic settings. ${ }^{1}$ We employ the device introduced by Lucas (1990) of organizing agents into families to simplify consideration of these distributional effects. With this device, we are able to characterize the effects of monetary injections in a stochastic environment. We show that this model can replicate salient features of exchange rate behavior. In particular, if monetary injections are highly persistent and if the fraction of agents in the asset market at a point in time is small enough, then nominal exchange rates in the model are highly volatile relative to inflation, money growth, and interest rate differentials, changes in nominal and real exchange rates are highly correlated and have roughly the same volatility, and both nominal and real exchange rates are highly persistent. In contrast, related models in Grilli and Roubini (1992) and Shlagenhauf and Wrase (1995) exploring the effect of monetary injections on exchange rates in open economy extensions of Lucas (1990) and Fuerst (1992) cannot generate large and persistent movements in exchange rates.

In the Grossman-Weiss-Rotemberg model, trading frictions are described by a free parameter governing both the length of time between agents' trips to the asset market and the fraction of agents in the asset market at a point in time. This paper is an exploration of the range of outcomes that

\footnotetext{
${ }^{1}$ Baxter et. al. (1991) compute equilibria of a closed economy version of the Grossman-Weiss-Rotemberg model.
} 
this model can produce as this parameter is varied. This exercise is thus similar to that in Lucas (1990), who concludes:

"There is a wealth of interesting data on flow of funds, turnover rates of various kinds of accounts, and so on that monetary theory ought to deal with but generally has not. To do so, we will need to get further away from complete markets in our theory, just as labor economists have had to in their attempts to account for their interesting turnover series. If the theory of the transactions demand for money is to move in this direction, it is clear that we will need formulations that place a smaller burden on the idea of idea of a fixed period than do the models in this paper. I have in mind not so much explaining the crucial time lags in the monetary system (though that would be nice, too) but just describing them with free parameters that can be more easily varied to fit data than the period length in the usual discrete time formulations."

Whether or not the frictions required in this model to match exchange rate data are consistent with micro data on trading patterns is a question we leave for future research.

\section{The Behavior of Exchange Rates}

The behavior of exchange rates since the end of the Bretton Woods era has been discussed extensively in the literature. See, for example, Meese and Rogoff (1983), Mussa (1986), Baxter and Stockman (1989), and Flood and Rose (1995). These, and other, articles document several salient facts. 
First, since the early 1970's the exchange rates for the industrial countries have been very volatile, particularly in comparison to the volatility of other variables such as inflation, money growth rates, or interest rates. Second, changes in nominal and real exchange rates are highly correlated and have roughly the same volatility. Third, movements in nominal and real exchange rates are highly persistent.

In tables 1 and 2 we present some statistics illustrating these features of the data on exchange rates for the currencies of the G-7 countries versus the US dollar. Each statistic reported in these tables is the mean of the corresponding statistic across the G-7 computed from monthly data covering the period Jan 1973-Dec 1994. In table 1, we see that the standard deviation of changes in monthly nominal exchange rates is large, particularly when compared with the standard deviation of inflation, money growth, or interest rate differentials across countries. Moreover, we see that changes in nominal and real exchange rates are highly correlated and have roughly the same standard deviation. In table 2, we see that both nominal and real exchange rates are highly persistent. The autocorrelations for these series decay smoothly and, for real exchange rates, are consistent with a half-life of roughly three years.

In what follows, we examine the extent to which the Grossman-Weiss and Rotemberg model of the impact of monetary policy on inflation, interest rates, and exchange rates can generate data with these features.

\section{The Model}

Time is discrete, and denoted $t=0,1,2, \ldots$ Let $s_{t} \in$ $S$ denote the exogenous aggregate state realized at $t$ and $s^{t}=\left(s_{0}, \ldots, s_{t}\right)$ denote the history of the state at $t$. Let 
$\pi\left(s^{t}\right)$ denote the unconditional probability of history $s^{t}$ and $\pi\left(s^{t+k} ; s^{t}\right)$ denote the probability of history $s^{t+k}$ conditional on history $s^{t}$.

There are two countries. We call the first domestic and the second foreign. Agents in this economy are organized in families each of which is composed of one parent and a continuum of children of measure $1 /(1-\gamma)$. All of the domestic families have the same preferences, endowments, and demographic structure, so we will consider the equilibrium behavior of a representative domestic family. Likewise, we consider the equilibrium behavior of a representative foreign family.

There are two goods: a domestic good and a foreign good. Neither of these goods are storable. The parent of the domestic family receives stochastic endowment $\left\{y\left(s^{t}\right)\right\}_{t=0}^{\infty}$ of the domestic good and the parent of the foreign family receives endowment $\left\{y^{*}\left(s^{t}\right)\right\}_{t=0}^{\infty}$ of the foreign good. We assume that members of a family cannot consume their own endowment. Instead, they sell their endowment for currency and use currency to purchase goods from other families. There are two currencies used to purchase goods: the domestic currency and the foreign currency. The domestic currency is used to purchase domestic goods and the foreign currency is used to purchase foreign goods. The supplies of the domestic and foreign currencies are denoted $\left\{M\left(s^{t}\right)\right\}_{t=0}^{\infty}$ and $\left\{M^{*}\left(s^{t}\right)\right\}_{t=0}^{\infty}$ respectively. The domestic government introduces new domestic currency by handing out lump sum transfers $\left\{\tau\left(s^{t}\right)\right\}_{t=0}^{\infty}$ of currency to the parent of the domestic family. The foreign government hands out transfers $\left\{\tau^{*}\left(s^{t}\right)\right\}_{t=0}^{\infty}$ to the parent of the foreign family.

There are two physically separate locations in which trade takes place: an asset market and a goods market. At the beginning of each period, currencies and nominal claims are 
traded in the asset market. After asset trade, currencies and goods are traded in the goods market. Parents and children perform separate roles in these markets.

Children carry currency which they use to purchase goods on extended trips to the goods market. These shopping trips have stochastic length. Each period, at the end of goods trading, each child either continues with his current shopping trip for at least one more period or returns home to his parent in the asset market. The probability that a child continues with his current shopping trip is $\gamma$, while the probability that he returns home to his parent in the asset market is $(1-\gamma)$. If a child returns home to his parent after goods trading at $s^{t}$, all his unspent currency is destroyed. We denote the total unspent home and foreign currency that is destroyed in equilibrium at $s^{t}$ by $\left\{d\left(s^{t}\right), d^{*}\left(s^{t}\right)\right\}_{t=0}^{\infty}$. These assumptions about the shopping technology imply that each family has measure 1 children returning home to the asset market at the end of each period. Those children that return home to the asset market after goods trade at $s^{t-1}$ receive a gift of currency from their parent in the asset market at $s^{t}$ and use that gift to finance a new shopping trip starting with goods trade at $s^{t}$. We denote the quantities of currency that parents give to their children in the asset market at $s^{t}$ by $\left\{a_{i}\left(s^{t}\right), a_{i}^{*}\left(s^{t}\right)\right\}_{t=0}^{\infty}$. Here the superscript $*$ indicates the foreign currency and the index $i=d, f$ indicates the amounts given to the children of the domestic and foreign families respectively.

Parents sell the family endowment in the goods market. Goods prices are denoted $\left\{p\left(s^{t}\right), p^{*}\left(s^{t}\right)\right\}_{t=0}^{\infty}$, so the domestic parent earns revenue $p\left(s^{t}\right) y\left(s^{t}\right)$ and the foreign parent earns revenue $p^{*}\left(s^{t}\right) y^{*}\left(s^{t}\right)$. The parents also receive lump sum transfers of currency from their governments, trade nominal contingent claims with each other in the asset mar- 
ket, and decide what gifts of currency $\left\{a_{i}\left(s^{t}\right), a_{i}^{*}\left(s^{t}\right)\right\}_{t=0}^{\infty}$ to make to their children that return home to the asset market.

We interpret $y\left(s^{t}\right)$ as goods sold in stores in the home country for the home currency, while $y^{*}\left(s^{t}\right)$ are goods sold in stores in the foreign country for the foreign currency. Given this interpretation, we consider the quantities $p^{*}\left(s^{t}\right) c_{h}^{*}\left(s^{t}\right)$ and $p\left(s^{t}\right) c_{f}\left(s^{t}\right)$ as expenditures of the domestic and foreign children respectively as tourists in the other country. Accordingly, we identify $p\left(s^{t}\right)$ and $p^{*}\left(s^{t}\right)$ with the domestic and foreign consumer price indices and consider the growth rate of these price levels to be the domestic and foreign inflation rates respectively ${ }^{2}$.

At $s^{t}$, home and foreign children are indexed by the currency holdings $\left(m_{i}, m_{i}^{*}\right) i=d, f$ that they carry into goods trading. For children who are continuing a shopping trip, these amounts are carried over from the previous period. For those who returned to their parent in the asset market at the end of the previous period, these amounts equal the gifts $\left(a_{i}\left(s^{t}\right), a_{i}^{*}\left(s^{t}\right)\right) i=d, f$. Children allocate their spending over time to maximize their utility from the current shopping trip. Namely, at $s^{t}$ children face current and future goods prices $\left\{p\left(s^{t+k}\right), p^{*}\left(s^{t+k}\right)\right\}_{k=0}^{\infty}$ and choose consumption $\left\{c_{i}\left(s^{t+k}\right), c_{i}^{*}\left(s^{t+k}\right)\right\}_{k=0}^{\infty}$ and currency to carry out of goods trading $\left\{m_{i}^{\prime}\left(s^{t+k}\right), m_{i}^{* \prime}\left(s^{t+k}\right)\right\}_{k=0}^{\infty}$ to solve

$$
U_{i}\left(s^{t} ; m, m^{*}\right)=
$$

\footnotetext{
${ }^{2}$ An alternative interpretation is that there is trade between the countries in the two final goods and that purchases of goods are required to be paid with the currency of the seller on the good. In this alternative interpretation we identify $p\left(s^{t}\right)$ and $p^{*}\left(s^{t}\right)$ with the Gross Domestic Product deflators of the domestic and foreign country respectively.
} 


$$
\max \sum_{k \geq 0}(\beta \gamma)^{k} \sum_{s^{t+k}} \pi\left(s^{t+k} ; s^{t}\right) u_{i}\left(c_{i}\left(s^{t+k}\right), c_{i}^{*}\left(s^{t+k}\right)\right)
$$

subject to constraints

$$
\begin{gathered}
p\left(s^{t+k}\right) c_{i}\left(s^{t+k}\right)=m\left(s^{t+k}\right)-m_{i}^{\prime}\left(s^{t+k}\right) \\
p^{*}\left(s^{t+k}\right) c_{i}^{*}\left(s^{t+k}\right)=m^{*}\left(s^{t+k}\right)-m_{i}^{* \prime}\left(s^{t+k}\right) \\
m\left(s^{t+k}, s_{t+k+1}\right)=m_{i}^{\prime}\left(s^{t+k}\right) \\
m^{*}\left(s^{t+k}, s_{t+k+1}\right)=m_{i}^{* \prime}\left(s^{t+k}\right) \\
m\left(s^{t}\right)=m, m^{*}\left(s^{t}\right)=m^{*}
\end{gathered}
$$

The functions $u_{i}, i=d, f$, are the children's period utility functions. The functions $U_{i}, i=d, f$, are the children's indirect utility functions for currency on the current shopping trip. We denote the decision rules for a child of country $i$ carrying currency $\left(m, m^{*}\right)$ at $s^{t}$ by $c_{i}\left(s^{t} ; m, m^{*}\right), c_{i}^{*}\left(s^{t} ; m, m^{*}\right)$, $m_{i}^{\prime}\left(s^{t} ; m, m^{*}\right)$, and $m_{i}^{* \prime}\left(s^{t} ; m, m^{*}\right)$.

Parents trade a complete set of nominal claims in the asset market. We write the parents' budget constraint as a date 0 budget constraint. Let $\left\{Q\left(s^{t}\right)\right\}_{t=0}^{\infty}$ denote the date and state contingent prices of a unit of the domestic currency delivered at $s^{t}$ in terms of units of the domestic currency at date 0 . Let $\left\{e\left(s^{t}\right)\right\}_{t=0}^{\infty}$ denote the date and state contingent spot exchange rates indicating the number of units of the domestic currency at $s^{t}$ required to purchase a unit of the foreign currency at $s^{t}$. Facing these prices for nominal claims, domestic parents choose quantities of currency $\left\{a_{h}\left(s^{t}\right), a_{h}^{*}\left(s^{t}\right)\right\}_{t=0}^{\infty} \geq 0$ to give to those of their children that return home to the asset market and amounts of currency $\left\{n_{h}\left(s^{t}\right), n_{h}^{*}\left(s^{t}\right)\right\}_{t=0}^{\infty} \geq 0$ to retain in the asset market subject to a budget constraint

$$
\sum_{t=0}^{\infty} \sum_{s^{t}} Q\left(s^{t}\right)\left(a_{h}\left(s^{t}\right)+n_{h}\left(s^{t}\right)+e\left(s^{t}\right)\left(a_{h}^{*}\left(s^{t}\right)+n_{h}^{*}\left(s^{t}\right)\right)-\tau\left(s^{t}\right)\right)=
$$


$\sum_{t=0}^{\infty} \sum_{s^{t}} \sum_{s_{t+1}} Q\left(s^{t}, s_{t+1}\right)\left(p\left(s^{t}\right) y\left(s^{t}\right)+n_{h}\left(s^{t}\right)+e\left(s^{t}, s_{t+1}\right) n_{h}^{*}\left(s^{t}\right)\right)$.

Likewise, the budget constraint for the foreign parent is

$$
\begin{aligned}
& \sum_{t=0}^{\infty} \sum_{s^{t}} Q\left(s^{t}\right)\left(a_{f}\left(s^{t}\right)+n_{f}\left(s^{t}\right)+e\left(s^{t}\right)\left(a_{f}^{*}\left(s^{t}\right)+n_{f}^{*}\left(s^{t}\right)-\tau^{*}\left(s^{t}\right)\right)\right)= \\
& \sum_{t=0}^{\infty} \sum_{s^{t}} \sum_{s_{t+1}} Q\left(s^{t}, s_{t+1}\right)\left(n_{f}\left(s^{t}\right)+e\left(s^{t}, s_{t+1}\right)\left(p^{*}\left(s^{t}\right) y^{*}\left(s^{t}\right)+n_{f}^{*}\left(s^{t}\right)\right)\right) .
\end{aligned}
$$

Domestic and foreign parents allocate currency to maximize the discounted expected utility of their children's shopping trips:

$$
\sum_{t=0}^{\infty} \beta^{t} \sum_{s^{t}} \pi\left(s^{t}\right) U_{i}\left(s^{t} ; a_{i}\left(s^{t}\right), a_{i}^{*}\left(s^{t}\right)\right)
$$

subject to their respective budget constraints.

We denote the number of children of country $i$ with currency holdings

$\left(m_{i}\left(s^{t}\right), m_{i}^{*}\left(s^{t}\right)\right) \leq\left(m, m^{*}\right)$ at the beginning of goods trade at $s^{t}$ by the cumulative distribution function $F_{i}\left(s^{t} ; m, m^{*}\right)$. The evolution of this cumulative distribution function through time is determined as follows.

$$
\begin{gathered}
F_{i}\left(s^{t+1} ; m, m^{*}\right)=\gamma \int_{x, x^{*}} I_{i}\left(s^{t} ; x, x^{*}, m, m^{*}\right) d F_{i}\left(s^{t} ; x, x^{*}\right)+ \\
J_{i}\left(s^{t+1} ; m, m^{*}\right)
\end{gathered}
$$

where

$$
I_{i}\left(s^{t} ; x, x^{*}, m, m^{*}\right) \equiv
$$

Indicator of $\left\{\left(x, x^{*}\right): m_{i}^{\prime}\left(s^{t} ; x, x^{*}\right) \leq m, m_{i}^{\prime *}\left(s^{t} ; x, x^{*}\right) \leq m^{*}\right\}$ $J_{i}\left(s^{t+1} ; m, m^{*}\right) \equiv$ Indicator of $\left\{a_{i}\left(s^{t+1}\right) \leq m, a_{i}^{*}\left(s^{t+1}\right) \leq m^{*}\right\}$ 
This law of motion preserves the measure of $F_{i}$. At $s^{0}$, measure $\gamma /(1-\gamma)$ of the children in each family hold initial endowments of currency in the goods market and measure 1 are home with the parent in the asset market. We assume that $F_{i}\left(s^{0}, \infty, \infty\right)=1 /(1-\gamma)$.

In equilibrium, the amounts of currency that are destroyed when children return home to their parents in the asset market are given by

$$
\begin{aligned}
& d\left(s^{t}\right)=(1-\gamma) \sum_{i=d, f} \int_{m, m^{*}} m_{i}^{\prime}\left(s^{t} ; m, m^{*}\right) d F_{i}\left(s^{t} ; m, m^{*}\right) \\
& d^{*}\left(s^{t}\right)=(1-\gamma) \sum_{i=d_{1}, f} \int_{m, m^{*}} m_{i}^{* \prime}\left(s^{t} ; m, m^{*}\right) d F_{i}\left(s^{t} ; m, m^{*}\right)
\end{aligned}
$$

The stock of domestic currency evolves according to

$$
M\left(s^{t}, s_{t+1}\right)=M\left(s^{t}\right)+\tau\left(s^{t}, s_{t+1}\right)-d\left(s^{t}\right) .
$$

The stock of the foreign currency evolves analogously. The resource constraints are given by:

$$
\begin{aligned}
y\left(s^{t}\right) & =\sum_{i=d, f} \int_{m, m^{*}} c_{i}\left(s^{t} ; m, m^{*}\right) d F_{i}\left(s^{t} ; m, m^{*}\right) \\
y^{*}\left(s^{t}\right) & =\sum_{i=d, f} \int_{m, m^{*}} c_{i}^{*}\left(s^{t} ; m, m^{*}\right) d F_{i}\left(s^{t} ; m, m^{*}\right) .
\end{aligned}
$$

Money market clearing is given by

$$
\begin{gathered}
M\left(s^{t}\right)=\sum_{i=d, f}\left(n_{i}\left(s^{t}\right)+\int_{m, m^{*}} m d F_{i}\left(s^{t} ; m, m^{*}\right)\right) \\
M^{*}\left(s^{t}\right)=\sum_{i=d, f}\left(n_{i}^{*}\left(s^{t}\right)+\int_{m, m^{*}} m^{*} d F_{i}\left(s^{t} ; m, m^{*}\right)\right)
\end{gathered}
$$


Equilibrium in this model is a collection of prices $\left\{p\left(s^{t}\right)\right.$, $\left.p^{*}\left(s^{t}\right), Q_{t}\left(s^{t}\right), e\left(s^{t}\right)\right\}$,endowments $\left\{y\left(s^{t}\right), y^{*}\left(s^{t}\right)\right\}$, distributions of cash holdings $\left\{F_{i}\left(s^{t} ; m, m^{*}\right)\right\}$, government policies and quantities of currency destroyed $\left\{\tau\left(s^{t}\right), \tau^{*}\left(s^{t}\right), d\left(s^{t}\right)\right.$, $\left.d^{*}\left(s^{t}\right), M\left(s^{t}\right), M^{*}\left(s^{t}\right)\right\}$, decision rules and indirect utility functions $\left\{c_{i}\left(s^{t} ; m, m^{*}\right)\right.$, $\left.c_{i}^{*}\left(s^{t} ; m, m^{*}\right), m_{i}^{\prime}\left(s^{t} ; m, m^{*}\right), m_{i}^{* \prime}\left(s^{t} ; m, m^{*}\right), U_{i}\left(s^{t} ; m, m^{*}\right)\right\}$, and allocations of currencies by the parents $\left\{a_{i}\left(s^{t}\right), n_{i}\left(s^{t}\right)\right.$, $\left.a_{i}^{*}\left(s^{t}\right), n_{i}^{*}\left(s^{t}\right)\right\}$, such that the decision rules and utilities solve (3.1), the parents' allocations of currencies solve (3.2), and equations (3.3) through (3.10) are satisfied.

\section{Characterizing Equilibrium}

In presenting the Grossman-Weiss and Rotemberg model here, we have employed the device suggested by Lucas (1990) of organizing agents into families to simplify the consideration of wealth effects. With this device, we can compute equilibria analytically for the specific case in which children have $\log$ utility and nominal interest rates are always positive. For this case, we characterize the equilibrium price levels, asset prices, and exchange rates in four propositions. In the first proposition, we show that if nominal interest rates are always positive, then bonds dominate currency in the asset market and parents do not hold currency in the asset market from one period to the next. In the second proposition, we solve for the children's decision rules and indirect utility. In the third proposition we solve for the distribution of currency and consumption across children as a function of monetary policy. In the fourth proposition, we show how the distribution of currency and consumption across children determines equilibrium asset prices, and exchange rates. 
Consider nominal interest rates in this model. The price at $s^{t}$ of a one period bond that pays off one unit of the home currency for certain at $t+1$ is given by

$$
\frac{1}{1+i\left(s^{t}\right)}=\sum_{s_{t+1}} \frac{Q\left(s^{t}, s_{t+1}\right)}{Q\left(s^{t}\right)}
$$

and that of a one period bond that pays off one unit of the foreign currency for certain at $t+1$ is given by

$$
\frac{1}{1+i^{*}\left(s^{t}\right)}=\sum_{s_{t+1}} \frac{Q\left(s^{t}, s_{t+1}\right) e\left(s^{t}, s_{t+1}\right)}{Q\left(s^{t}\right) e\left(s^{t}\right)} .
$$

We refer to $\log \left(1+i\left(s^{t}\right)\right)$ and $\log \left(1+i^{*}\left(s^{t}\right)\right)$ as the home and foreign nominal short-term interest rates respectively.

Assumption 1: $i\left(s^{t}\right), i^{*}\left(s^{t}\right)>0$ for all $s^{t}$.

Proposition 1: In equilibria in which nominal interest rates are always positive, then parents' currency holdings in the asset market are given by

$$
\left\{n_{i}\left(s^{t}\right), n_{i}^{*}\left(s^{t}\right)\right\}_{t=0}^{\infty}=0 .
$$

Proof: Given assumption 1, bonds dominate cash in the sense that it is cheaper for the parents to obtain currency in the asset market at $s^{t+1}$ by purchasing bonds at $s^{t}$ than it is for them to hold the currency in the asset market from $s^{t}$ to $s^{t+1}$. The cost to the parent of holding a unit of domestic currency in the asset market at $s^{t}$ is $Q\left(s^{t}\right)$, while the benefit is $\sum_{s_{t+1}} Q\left(s^{t}, s_{t+1}\right)$. Assumption 1 implies that the cost exceeds the benefit for all $s^{t}$. Likewise for the foreign currency.

This proposition implies that when interest rates are positive, asset prices adjust to induce the parents to give all the new currency injected into the economy at $s^{t}$ to those children who happen to be home with their parent in the asset 
market at that time. Since these children cannot trade with the other children in the goods market, these currency injections have a disproportionate impact on their currency holdings and consumption.

Assumption 2: Let the domestic children have period utility function $u_{d}\left(c, c^{*}\right)=\theta \log (c)+(1-\theta) \log \left(c^{*}\right)$ and let the foreign children have period utility function $u_{f}\left(c, c^{*}\right)=$ $(1-\theta) \log (c)+\theta \log \left(c^{*}\right)$. Choices for the value of the parameter $\theta>1 / 2$ reflect the preference of children for their own country's good.

Proposition 2: With preferences as given in assumption 2, a child entering goods trade at $s^{t}$ with currency $\left(m, m^{*}\right)$ spends

$$
\begin{gathered}
c_{i}\left(s^{t} ; m, m^{*}\right)=(1-\beta \gamma) m / p\left(s^{t}\right) \\
c_{i}^{*}\left(s^{t} ; m, m^{*}\right)=(1-\beta \gamma) m^{*} / p^{*}\left(s^{t}\right)
\end{gathered}
$$

and carries currency

$$
\begin{aligned}
m_{i}^{\prime}\left(s^{t} ; m, m^{*}\right) & =\beta \gamma m \\
m_{i}^{* \prime}\left(s^{t} ; m, m^{*}\right) & =\beta \gamma m^{*}
\end{aligned}
$$

out of goods trade. The indirect utility functions for currency for the domestic and foreign children are given by

$U_{d}\left(s^{t} ; m, m^{*}\right)=\frac{1}{1-\beta \gamma}\left(\theta \log (m)+(1-\theta) \log \left(m^{*}\right)\right)+A_{d}\left(s^{t}\right)$,

$U_{f}\left(s^{t} ; m, m^{*}\right)=\frac{1}{1-\beta \gamma}\left((1-\theta) \log (m)+\theta \log \left(m^{*}\right)\right)+A_{f}\left(s^{t}\right)$, where $A_{i}\left(s^{t}\right)$ is given by

$$
A_{d}\left(s^{t}\right)=\sum_{k=0}^{\infty}(\beta \gamma)^{k} \sum_{s^{t+k}} \pi\left(s^{t+k} ; s^{t}\right)[\log (1-\beta \gamma)+k \log (\beta \gamma)-
$$




$$
\begin{gathered}
\left.\theta \log \left(p\left(s^{t+k}\right)\right)-(1-\theta) \log \left(p^{*}\left(s^{t+k}\right)\right)\right], \\
A_{f}\left(s^{t}\right)=\sum_{k=0}^{\infty}(\beta \gamma)^{k} \sum_{s^{t+k}} \pi\left(s^{t+k} ; s^{t}\right)[\log (1-\beta \gamma)+k \log (\beta \gamma)- \\
\left.(1-\theta) \log \left(p\left(s^{t+k}\right)\right)-\theta \log \left(p^{*}\left(s^{t+k}\right)\right)\right] .
\end{gathered}
$$

Proof: It is straightforward to verify that these decision rules satisfy the sufficient first-order and transversality conditions associated with the (convex) children's utility maximization problem and that $U_{i}$ is the discounted expected utility obtained.

We use this proposition to trace the flow of cash through the economy as follows. By definition, $M\left(s^{t}\right)$ is the stock of the domestic currency at the beginning of goods trade at $s^{t}$. In equilibria with positive interest rates, the parents will not hold currency in the asset market, so $M\left(s^{t}\right)$ is held entirely by children in the goods market. Proposition 2 implies that each child spends the constant fraction $(1-\beta \gamma)$ of his currency holdings, so total spending of the domestic currency is $(1-\beta \gamma) M\left(s^{t}\right)$. This quantity of currency spent equals the domestic parent's receipts $p\left(s^{t}\right) y\left(s^{t}\right)$ from selling the domestic endowment in the goods market, so in equilibrium

$$
p\left(s^{t}\right) y\left(s^{t}\right)=(1-\beta \gamma) M\left(s^{t}\right) .
$$

Likewise, for the foreign currency, we have

$$
p^{*}\left(s^{t}\right) y^{*}\left(s^{t}\right)=(1-\beta \gamma) M^{*}\left(s^{t}\right)
$$

As a result, we obtain solutions for the equilibrium price levels

$$
\begin{aligned}
p\left(s^{t}\right) & =(1-\beta \gamma) \frac{M\left(s^{t}\right)}{y\left(s^{t}\right)} \\
p^{*}\left(s^{t}\right) & =(1-\beta \gamma) \frac{M^{*}\left(s^{t}\right)}{y^{*}\left(s^{t}\right)}
\end{aligned}
$$


Thus, in our model, as long as interest rates are positive, the velocity of currency per period is constant and given by $(1-\beta \gamma)$. In the case that $\gamma=0$, so shopping trips last one period, per-period velocity is one as it is in the standard cash-in-advance model. The larger is $\gamma$, the longer are shopping trips, and the lower is per-period velocity. As in a standard quantity-theory model, inflation is given by the growth rate of the money supply divided by the growth rate of the endowment.

Now consider the flow of currency through asset markets. From proposition 2 , we have that children at $s^{t-1}$ spend currency $(1-\beta \gamma) M\left(s^{t-1}\right)$ and $(1-\beta \gamma) M^{*}\left(s^{t-1}\right)$ in the goods market and retain currency $\beta \gamma M\left(s^{t-1}\right)$ and $\beta \gamma M^{*}\left(s^{t-1}\right)$ at the end of goods trading. Only fraction $\gamma$ of the children remain in the goods market. The other $(1-\gamma)$ of the children return to their parents in the asset market. Thus, at $s^{t}$, children remaining in the goods market have carried over currency $\beta \gamma^{2} M\left(s^{t-1}\right)$ and $\beta \gamma^{2} M^{*}\left(s^{t-1}\right)$ from the previous period and parents, in total, have currency $M\left(s^{t}\right)-\beta \gamma^{2} M\left(s^{t-1}\right)$ and $M^{*}\left(s^{t}\right)-\beta \gamma^{2} M^{*}\left(s^{t-1}\right)$ in the asset market. Since parents do not hold cash in the asset market when interest rates are positive, we have

$$
\begin{gathered}
\sum_{i} a_{i}\left(s^{t}\right)=M\left(s^{t}\right)-\beta \gamma^{2} M\left(s^{t-1}\right) \\
\sum_{i} a_{i}^{*}\left(s^{t}\right)=M^{*}\left(s^{t}\right)-\beta \gamma^{2} M^{*}\left(s^{t-1}\right) .
\end{gathered}
$$

To calculate how currency is divided between domestic and foreign children in the asset market, consider the first-order conditions of the parents' problem. For the domestic parent, these include

$$
Q\left(s^{t}\right)=\lambda \beta^{t} \pi\left(s^{t}\right) \frac{\partial U_{d}\left(s^{t} ; a_{d}\left(s^{t}\right), a_{d}^{*}\left(s^{t}\right)\right)}{\partial a},
$$


where $\lambda$ is the Lagrange multiplier on the parent's date 0 budget constraint. From proposition 2, we can calculate the marginal utility of currency and obtain

$$
Q\left(s^{t}\right)=\lambda \beta^{t} \pi\left(s^{t}\right) \frac{\theta}{(1-\beta \gamma) a_{d}\left(s^{t}\right)},
$$

Similarly, from the foreign parent's problem, we obtain first order condition

$$
Q\left(s^{t}\right)=\lambda^{*} \beta^{t} \pi\left(s^{t}\right) \frac{(1-\theta)}{(1-\beta \gamma) a_{f}\left(s^{t}\right)},
$$

where $\lambda^{*}$ is the Lagrange multiplier on the foreign parent's budget constraint. Equations (4.3) and (4.4) imply

$$
a_{f}\left(s^{t}\right)=\frac{(1-\theta)}{\theta} \frac{\lambda^{*}}{\lambda} a_{d}\left(s^{t}\right)
$$

This result gives the following proposition

Proposition 3: The equilibrium quantities $\left\{a_{d}\left(s^{t}\right), a_{d}^{*}\left(s^{t}\right)\right\}_{t=0}^{\infty}$ are given by

$$
\begin{gathered}
a_{d}\left(s^{t}\right)=\theta z\left(s^{t}\right) M\left(s^{t}\right) \\
a_{d}^{*}\left(s^{t}\right)=(1-\theta) z^{*}\left(s^{t}\right) M^{*}\left(s^{t}\right)
\end{gathered}
$$

where

$$
\begin{gathered}
z\left(s^{t}\right)=\frac{\lambda}{\theta \lambda+(1-\theta) \lambda^{*}}\left(1-\frac{\beta \gamma^{2}}{\mu\left(s^{t}\right)}\right) \\
z^{*}\left(s^{t}\right)=\frac{\lambda}{(1-\theta) \lambda+\theta \lambda^{*}}\left(1-\frac{\beta \gamma^{2}}{\mu^{*}\left(s^{t}\right)}\right),
\end{gathered}
$$

and $\mu\left(s^{t}\right)=M\left(s^{t}\right) / M\left(s^{t-1}\right)$ is the growth rate of the domestic currency supply and $\mu^{*}\left(s^{t}\right)$ is the growth rate of the foreign currency supply.

The expressions (4.5) and (4.6) make clear how monetary injections result in a redistribution of currency and 
consumption in this model. In particular, the terms $z\left(s^{t}\right)$ and $z^{*}\left(s^{t}\right)$ in these expressions are proportional to the shares of the total domestic and foreign currency supplies given to domestic children in the asset market at $s^{t}$. Since every child spends a constant fraction of his currency holdings each period, these terms $z\left(s^{t}\right)$ and $z^{*}\left(s^{t}\right)$ are also proportional to the shares of the domestic and foreign endowments $y\left(s^{t}\right), y^{*}\left(s^{t}\right)$ consumed by those children at $s^{t}$. We can compute the impact of monetary injections on the currency holdings and consumption of children in the asset market through the terms $z\left(s^{t}\right)$ and $z^{*}\left(s^{t}\right)$.

Consider first the case in which the parameter $\gamma=0$. In this case, shopping trips last only one period, and all children return to the asset market every period. Here, $z\left(s^{t}\right)$ and $z^{*}\left(s^{t}\right)$ are constant. Currency and consumption are distributed across children every period in proportion to the wealth of their parents at date 0 , and all children within a family have identical currency holdings and consumption. In this sense, our model nests the standard constant-velocity cash in advance model when $\gamma=0$.

Consider now the case in which $\gamma>0$. Here, monetary injections at $s^{t}$ have an amplified impact on the currency holdings of those children in the asset market at $s^{t}$ and thus an amplified impact on their consumption at $s^{t}$. This impact is captured in the terms $z\left(s^{t}\right)$ and $z^{*}\left(s^{t}\right)$. The magnitude of the impact of changes in the money growth rate on the distribution of currency holdings and consumption across children changes with the parameter $\gamma$ in the natural way. In particular, the elasticity of $z\left(s^{t}\right)$ with respect to $\mu\left(s^{t}\right)$ is given by

$$
\frac{\partial z}{\partial \mu} \frac{\mu}{z}=\frac{\beta \gamma^{2}}{\mu-\beta \gamma^{2}} .
$$

Thus, the larger is $\gamma$, the larger is this elasticity. Given the 
demographics of the model, the fraction of children in the asset market at any point in time is $(1-\gamma)$. When $\gamma$ is larger, shopping trips are longer, fewer children are in the asset market, and monetary injections must be absorbed by this smaller number of children. As a result, monetary injections of a given size have a larger impact on the currency holdings and consumption of those children.

Note that, holding fixed $\gamma$, the elasticity of $z$ with respect to $\mu$ is declining in $\mu$. Thus, at higher average money growth and inflation rates, the share of currency and consumption going to children in the asset market becomes less sensitive to a one percentage point change in money growth and inflation rates because these children are, on average, receiving a larger share of the total money stock. As we shall see below, this result also implies that asset prices and exchange rates are also less sensitive to changes in money growth and inflation rates when average inflation is high.

Observe that the only stochastic elements in the terms $z\left(s^{t}\right)$ and $z^{*}\left(s^{t}\right)$ are the current money growth rates $\mu\left(s^{t}\right)$ and $\mu^{*}\left(s^{t}\right)$. This implies that monetary policy will have a persistent effect on the distribution of currency holdings and consumption across children if money growth rates are persistent and a transitory effect if money growth rates are transitory. The parameter $\gamma$ determining the length of shopping trips has no bearing on the question of whether or not monetary policy will have a persistent effect on the distribution of currency holdings and consumption across children. Instead, as we saw above, the parameter $\gamma$ only determines the magnitude of the impact of the current monetary injection on the shares of currency and consumption going to children currently in the asset market.

Now consider the impact of monetary policy on nominal 
asset prices. From (4.3) and (4.5) we have

$$
Q\left(s^{t}\right)=\frac{\lambda \beta^{t} \pi\left(s^{t}\right)}{z\left(s^{t}\right) M\left(s^{t}\right)} .
$$

Likewise, for the foreign currency we have

$$
Q\left(s^{t}\right) e\left(s^{t}\right)=\frac{\lambda \beta^{t} \pi\left(s^{t}\right)}{z^{*}\left(s^{t}\right) M^{*}\left(s^{t}\right)} .
$$

As these formulas indicate, the price of a unit of currency at $s^{t}$ is inversely proportional to the amount of that currency in the hands of children in the asset market at $s^{t}$. In the case that $\gamma=0$, monetary injections have no impact on the distribution of currency across children, so the price of a unit of currency at $s^{t}$ falls one percent for each one percent increase in the aggregate supply of that currency at $s^{t}$. On the other hand, when $\gamma>0$, then monetary injections at $s^{t}$ have a disproportionately large impact on the share of that currency held by children in the asset market at $s^{t}$. As a result, these injections have a disproportionately large impact on the price of that currency at $s^{t}$. As we have discussed above, this impact is larger the larger is $\gamma$.

We can also calculate the impact of monetary policy on real asset prices. Observe that $Q\left(s^{t}\right) p\left(s^{t}\right)$ is the price at date 0 of a claim to enough domestic currency at $s^{t}$ to purchase one unit of the domestic good at $s^{t}$. Likewise, $Q\left(s^{t}\right) e\left(s^{t}\right) p^{*}\left(s^{t}\right)$ is the price at date 0 of a claim to one unit of the foreign good at $s^{t}$. Using (4.1) and (4.2), these prices are given by

$$
\begin{gathered}
Q\left(s^{t}\right) p\left(s^{t}\right)=(1-\beta \gamma) \frac{\lambda \beta^{t} \pi\left(s^{t}\right)}{z\left(s^{t}\right) y\left(s^{t}\right)} \\
Q\left(s^{t}\right) e\left(s^{t}\right) p^{*}\left(s^{t}\right)=(1-\beta \gamma) \frac{\lambda \beta^{t} \pi\left(s^{t}\right)}{z^{*}\left(s^{t}\right) y^{*}\left(s^{t}\right)} .
\end{gathered}
$$


As these formulas indicate, real asset prices drop one percent for every one-percent increase in the shares $z$ and $z^{*}$ of the aggregate endowment consumed by children in the asset market. Since monetary injections increase this share, monetary injections depress real asset prices and their effect is larger, the larger is $\gamma$.

We have characterized the impact of monetary injections on date 0 real and nominal asset prices. These contingent asset prices can be used to price any nominal or real security. In the next proposition, we use these asset prices to construct real and nominal interest rates and exchange rates.

Proposition 4: When children have log utility and interest rates are always positive, nominal interest rates and exchange rates are given by

$$
\begin{gathered}
\frac{1}{1+i\left(s^{t}\right)}=z\left(s^{t}\right) M\left(s^{t}\right) \beta \sum_{s^{t+1}} \frac{\pi\left(s^{t+1} ; s^{t}\right)}{z\left(s^{t+1}\right) M\left(s^{t+1}\right)} \\
\frac{1}{1+i^{*}\left(s^{t}\right)}=z^{*}\left(s^{t}\right) M^{*}\left(s^{t}\right) \beta \sum_{s^{t+1}} \frac{\pi\left(s^{t+1} ; s^{t}\right)}{z^{*}\left(s^{t+1}\right) M^{*}\left(s^{t+1}\right)}, \\
e\left(s^{t}\right)=\frac{z\left(s^{t}\right) M\left(s^{t}\right)}{z^{*}\left(s^{t}\right) M^{*}\left(s^{t}\right)} .
\end{gathered}
$$

Real interest rates, here modelled as the rate of return on one-period sure claims to the domestic and foreign good are denoted $r\left(s^{t}\right)$ and $r^{*}\left(s^{t}\right)$ respectively and are given by

$$
\begin{gathered}
\frac{1}{1+r\left(s^{t}\right)}=z\left(s^{t}\right) y\left(s^{t}\right) \beta \sum_{s^{t+1}} \frac{\pi\left(s^{t+1} ; s^{t}\right)}{z\left(s^{t+1}\right) y\left(s^{t+1}\right)}, \\
\frac{1}{1+r^{*}\left(s^{t}\right)}=z^{*}\left(s^{t}\right) y^{*}\left(s^{t}\right) \beta \sum_{s^{t+1}} \frac{\pi\left(s^{t+1} ; s^{t}\right)}{z^{*}\left(s^{t+1}\right) y^{*}\left(s^{t+1}\right)},
\end{gathered}
$$


while real exchange rates, denoted $x\left(s^{t}\right)=e\left(s^{t}\right) p^{*}\left(s^{t}\right) / p\left(s^{t}\right)$, are given by

$$
x\left(s^{t}\right)=\frac{z\left(s^{t}\right) y\left(s^{t}\right)}{z^{*}\left(s^{t}\right) y^{*}\left(s^{t}\right)} .
$$

Proposition 4 implies that monetary policy has two effects on exchange rates in this model. First, in this model, as in a quantity-theory model, an increase in the domestic money stock $M\left(s^{t}\right)$ results in an increase in the domestic price level and a deprecation of the domestic currency relative to the foreign currency. Second, in this model, unlike a quantity-theory model, an increase in the domestic money stock also affects the real exchange rate. Since the children in the asset market receive a disproportionate share of the increase in the domestic money stock, their consumption of the domestic good rises relative to their consumption of the foreign good and the price of the domestic good relative to the foreign good falls. As we saw above, this effect is larger, the larger is $\gamma$.

The persistence of the effect of monetary policy on exchange rates depends only on the persistence of the difference in money growth rates across countries. Since, the real exchange rate is determined by the relative amounts of the domestic and foreign goods consumed by children currently in the asset market, the current real exchange rate depends only on current endowments and current money growth rates. Thus, transitory movements in the money growth differential across countries will induce transitory movements in the real exchange rate while persistent movements in the money growth differential across countries will induce persistent movements in the real exchange rate. Changes in the real and nominal exchange rate will be correlated, since both depend on the differential of the money growth rates across countries. 
Monetary policy has two effects on interest rates in this model as well. First, in this model, as in a quantity-theory model, events at date $t$ which signal higher money growth between dates $t$ and $t+1$ raise expectations of inflation and nominal interest rates. Second, in this model, unlike a quantity theory model, differences in money growth rates at dates $t$ and $t+1$ also affect the real interest rate. Again, since children in the asset market receive a disproportionate share of monetary injections, changes in money growth rates from $t$ to $t+1$ redistribute consumption between those children who are in the asset market at $t$ and those in the asset market at $t+1$. Since parents prefer to distribute consumption evenly across their children, these changes in money growth rates induce changes in the equilibrium prices at which parents can transfer consumption from children in the asset market at $t$ and those in the asset market at $t+1$.

Consider, for example, a case in which endowments $y\left(s^{t}\right)$ are constant and money growth rates satisfy

$$
\mu\left(s^{t}, s_{t+1}\right)=\bar{\mu}^{1-\rho} \mu\left(s^{t}\right)^{\rho}
$$

with $0<\rho<1$ for all $s_{t+1}$. Here, the parameter $\rho$ governs the persistence of money growth from $s^{t}$ to $s^{t+1}$. In this case, we can compute the real interest rate as

$$
\log \left(1+r\left(s^{t}\right)\right)=\log \left(1-\frac{\beta \gamma^{2}}{\bar{\mu}^{1-\rho} \mu\left(s^{t}\right)^{\rho}}\right)-\log \left(1-\frac{\beta \gamma^{2}}{\mu\left(s^{t}\right)}\right)-\log (\beta)
$$

and the nominal interest rate as

$$
\log \left(1+i\left(s^{t}\right)\right)=\log \left(1+r\left(s^{t}\right)\right)+(1-\rho) \log (\bar{\mu})+\rho \log \left(\mu\left(s^{t}\right)\right) .
$$

The elasticity of the real interest rate with respect to the money growth rate $\mu\left(s^{t}\right)$ evaluated at $\mu\left(s^{t}\right)=\bar{\mu}$ is given by

$$
\frac{d \log \left(1+r\left(s^{t}\right)\right)}{d \log \left(\mu\left(s^{t}\right)\right)}=(\rho-1) \frac{\beta \gamma^{2}}{\bar{\mu}-\beta \gamma^{2}},
$$


while the elasticity of the nominal interest rate with respect to the money growth rate $\mu\left(s^{t}\right)$ evaluated at $\mu\left(s^{t}\right)=\bar{\mu}$ is given by

$$
\frac{d \log \left(1+i\left(s^{t}\right)\right)}{d \log \left(\mu\left(s^{t}\right)\right)}=(\rho-1) \frac{\beta \gamma^{2}}{\bar{\mu}-\beta \gamma^{2}}+\rho .
$$

When $\gamma>0$ and $\rho<1$, an increase in the money growth rate at $s^{t}$ decreases the real interest rate. Clearly the magnitude of this effect depends on the parameter $\gamma$ because it depends again on the elasticity of the share $z$ of output consumed by children in the asset market with respect to money growth $\mu$. Moreover, the magnitude of the effect also depends on the persistence of money growth. If increases in money growth $\mu\left(s^{t}\right)$ are very persistent, so $\rho$ is very close to one, then these increases in the money growth rate have only a small negative effect on the real interest rate because these increases in money growth have only a small effect on the relative shares of output consumed by those children in the asset market at $t$ and those children in the asset market at $t+1$. On the other hand, if increases in money growth $\mu\left(s^{t}\right)$ are transitory, so $\rho$ is small, then they have a large negative impact on real interest rates because they result in a large increase the consumption of those children in the asset market at $t$ relative to those children in the asset market at $t+1$.

Combining these implications of proposition 4, we see that if we choose domestic and foreign money growth rates that are persistent and not highly correlated across countries, then the model will produce nominal and real exchange rates that are persistent and volatile relative to inflation and money growth differentials and interest rates that are close to their Fisherian fundamentals. In the next section, we present a numerical example to illustrate these results. 
Compare the implications of our model for the impact of monetary policy on inflation, asset prices, and exchange rates to those of the models in Lucas (1990), and Fuerst (1992), and their open economy variants in Grilli and Roubini (1992) and Schlagenhauf and Wrase (1995). Schlagenhauf and Wrase (1995) demonstrate quantitatively that their open economy variant of the Fuerst (1992) model cannot match the volatility and persistence of real exchange rates. Moreover, Grilli and Roubini (1992) show analytically that the impact of a monetary injection on the real exchange rate and the short-term interest is the same. Thus, monetary shocks in this alternative model cannot produce exchange rates that are substantially more volatile than interest rate differentials.

\section{A Numerical Example}

In this section, we solve a numerical example to show that monetary shocks in our model can generate nominal exchange rates that are persistent and substantially more volatile than inflation, money growth, and interest rates, together with real exchange rates that are also persistent, are highly correlated with nominal exchange rates, and have nearly the same volatility as nominal exchange rates.

Consider an economy in which endowments $\left\{y_{t}, y_{t}^{*}\right\}$ are constant and equal, initial wealth is distributed between domestic and foreign parents so that the Lagrange multipliers on the parents' date 0 budget constraints, $\lambda$ and $\lambda^{*}$, are equal, and government sets lump sum transfers of currency to parents of families so that quantities

$$
z_{t}=1-\frac{\beta \gamma^{2}}{\mu_{t}}, \text { and } z_{t}^{*}=1-\frac{\beta \gamma^{2}}{\mu_{t}^{*}}
$$


follow autoregressive processes given by

$$
\begin{aligned}
& \log \left(z_{t+1}\right)=(1-\rho) \log (\bar{z})+\rho \log \left(z_{t}\right)+\log \left(\epsilon_{t+1}\right), \\
& \log \left(z_{t+1}^{*}\right)=(1-\rho) \log (\bar{z})+\rho \log \left(z_{t}^{*}\right)+\log \left(\epsilon_{t+1}^{*}\right),
\end{aligned}
$$

where $\left(\log \epsilon_{t}, \log \epsilon_{t}^{*}\right)$ are independent across time and normal with mean 0 , variance $\sigma_{\epsilon}^{2}$, and contemporaneous correlation $\rho_{\epsilon \epsilon}$. Note that, given the first-order approximation,

$$
\log \left(\mu_{t}\right)-\log (\bar{\mu})=\left(\frac{\bar{z}}{1-\bar{z}}\right)\left(\log \left(z_{t}\right)-\log (\bar{z})\right)
$$

our specification for monetary policy is similar to one in which the logarithm of money growth (and inflation) follows a first-order autoregressive process with long-run variance

$$
\sigma_{\mu}^{2}=\left(\frac{\bar{z}}{1-\bar{z}}\right)^{2} \frac{\sigma_{\epsilon}^{2}}{1-\rho^{2}} .
$$

We choose the specification (5.1) for monetary policy because we can characterize short term nominal interest rates analytically in this case. Specifically, one-period nominal interest rates are given by

$$
\begin{gathered}
\log \left(1+i_{t}\right)=2 \log (\gamma)-\log \left[\left(\frac{z_{t}}{\bar{z}}\right)^{1-\rho} \exp \left(\sigma_{\epsilon}^{2} / 2\right)-z_{t}\right]_{(5 .} \\
\log \left(1+i_{t}^{*}\right)=2 \log (\gamma)-\log \left[\left(\frac{z_{t}^{*}}{\bar{z}}\right)^{1-\rho} \exp \left(\sigma_{\epsilon}^{2} / 2\right)-z_{t}^{*}\right] .
\end{gathered}
$$

With constant endowments, inflation (denoted $\pi$ and $\pi^{*}$ ) and the growth rates of the money stocks $\mu_{t}$ and $\mu_{t}^{*}$ are given by

$$
\log \left(\pi_{t}\right)=\log \left(\mu_{t}\right)=\log (\beta)+2 \log (\gamma)-\log \left(1-z_{t}\right)
$$




$$
\log \left(\pi_{t}^{*}\right)=\log \left(\mu_{t}^{*}\right)=\log (\beta)+2 \log (\gamma)-\log \left(1-z_{t}^{*}\right) .
$$

The logarithm of the real exchange rate is given by

$$
\log \left(x_{t}\right)=\log \left(z_{t}\right)-\log \left(z_{t}^{*}\right)
$$

and that of the nominal exchange rate by

$$
\log \left(e_{t}\right)=\log \left(x_{t}\right)+\log \left(M_{t}\right)-\log \left(M_{t}^{*}\right) .
$$

The parameters we choose for this example are

$$
\begin{array}{cccccc}
\gamma & \beta & \bar{z} & \rho & \sigma_{\epsilon} & \rho_{\epsilon \epsilon} \\
.989 & .997 & .03 & .98 & .03 & .50
\end{array}
$$

We simulated the model for 10,000 observations to generate moments in Tables 3 and 4 analogous to those reported from data in tables 1 and 2 . The six parameters in this example are chosen so that our model in large samples reproduces six moments similar to those observed in the data for the G-7. These moments are the standard deviation of changes in monthly real exchange rates ( $37 \%$ at an annual frequency as reported in table 1 ), the half-life of real exchange rates (here set at 36 months), the mean of inflation $(6.5 \%$ at an annual frequency), the mean of interest rates (9.5\% at an annual frequency), the standard deviation of monthly inflation (6\% at an annual frequency as reported in table 1 ), and the standard deviation of inflation differentials (also $6 \%$ at an annual frequency as reported in table 1).

The mapping between these six parameters and these six moments can be approximated as follows. From 5.6, we see the variance of the first difference of the log of real exchange rates is given by $4\left(1-\rho_{\epsilon \epsilon}\right) \sigma_{\epsilon}^{2} /(1+\rho)$ and the persistence of real exchange rates is determined by the parameter $\rho$. The mean of the $\log$ of inflation is given by the mean of the 
term $\log (\beta)+2 \log (\gamma)-\log (1-z)$ and the mean of the $\log$ of nominal interest rates for $\rho$ close to one is approximately the mean of $2 \log (\gamma)-\log (1-z)$. To a first order approximation, the variance of the $\log$ of inflation is given by $[\bar{z} /(1-\bar{z})]^{2} \sigma_{\epsilon}^{2} /\left(1-\rho^{2}\right)$ and the variance of inflation differentials by $2\left(1-\rho_{\epsilon \epsilon}\right)[\bar{z} /(1-\bar{z})]^{2} \sigma_{\epsilon}^{2} /\left(1-\rho^{2}\right)$.

In this numerical example, we have chosen a high value for the persistence $\rho$ of monetary policy. We chose this value so that the model would generate persistent real exchange rates. As a consequence of this choice, nominal interest rates in this model are close to their Fisherian fundamentals. In fact the correlation between interest rates and inflation in this example as reported in table 3 is close to one and nominal interest rates are less volatile than inflation. If a smaller value of $\rho$ is chosen, real exchange rates are less persistent, nominal interest rates become negatively correlated with inflation and substantially more volatile.

In this numerical example we have also chosen a low value for the fraction $(1-\gamma)$ of children in the asset market. The choice of the parameter $\gamma$ close to one is necessary to match the relative variances of real exchange rates and inflation. In this example, the ratio of the variance of the $\log$ of inflation to the variance of the first difference of the log of real exchange rates is given by the term $(\bar{z} /(1-\bar{z}))^{2}(1+\rho) /\left(1-\rho^{2}\right)$. In data as reported in table 1 , this ratio is 0.027 . Thus, to match the relative variance of inflation differentials and innovations to real exchange rates given a the high value of $\rho$ we have chosen to match the persistence of real exchange rates, we must choose $\bar{z}$ on the order of 0.03 . The parameter $\bar{z}$ is the average share of currency and consumption going to children in the asset market. It is only when this average share is small that small changes in money growth rates have large effects on 
the portfolios of children in the asset market. Given average inflation rates observed in the data, this share is small only if the fraction of children in the asset market is small.

\section{Conclusion}

In this paper, we have characterized the impact of monetary policy on inflation, asset prices, and exchange rates in the Grossman-Weiss-Rotemberg model. We have shown that this model can reproduce some salient features of exchange rate behavior if its parameters are chosen so that only a very small fraction of agents participate in open market орегаtions at any point in time and if domestic and foreign money growth rates are persistent and not highly correlated across countries. In particular, given these assumptions, the model generates nominal exchange rates that are highly volatile relative to inflation, money growth, or interest rate differentials, movements in real exchange rates that are highly correlated with movements in nominal exchange rates and also very volatile, and movements in nominal and real exchange rates that are highly persistent. 


\section{References}

Backus, David, K., Silverio Foresi, and Chris I. Telmer, (1994) "The Forward Premium Anomaly: Three Examples in Search of A Solution", mimeo, New York University Stern School of Business

Baumol, William J., (1952), "The Transactions Demand for Cash: An Inventory Theoretic Approach", Quarterly Journal of Economics, November, vol. 66 pp. 545-556

Baxter, Marianne, Stephen N. Fisher, Robert G. King, and K. Geert Rouwenhorst, (1991). "The Liquidity Effect in General Equilibrium", mimeo, University of Virginia

Baxter, Marianne and Alan C. Stockman, (1989), "Business Cycles and the Exchange Rate Regime:Some international evidence", Journal of Monetary Economics, May, vol. 23, no. 3 pp. $377-400$

Flood, Robert P. and Andrew K. Rose, (1995). "Fixing Exchange Rates: A virtual quest for fundamentals", Journal of Monetary Economics, August, Vol.36, no.1, pp. 3-38

Fuerst, Timothy, (1992), "Liquidity, Loanable Funds, and Real Activity", Journal of Monetary Economics, vol. 29, pp.3-24. 
Grilli, Vittorio and Nouriel Roubini, (1992), "Liquidity and Exchange Rates", Journal of International Economics, vol. $32 \mathrm{Pp} 339-352$

Hodrick, Robert J., (1987), The Empirical Evidence on the Efficiency of Forward and Futures Foreign Exchange Markets, Harwood Academic Publishers, Chur. Switzerland.

Jovanovic, Boyan, (1982), "Inflation and Welfare in the Steady State", Journal of Political Economy, vol. 90, no. 3 , pp.561-577

Lewis, Karen K., (1995), "Puzzles in International Financial Markets", in G. Grossman and K. Rogoff eds. Handbook of International Economics, vol. III Elsevier Science B.V.

Lucas, Robert E. Jr., (1990), "Liquidity and Interest Rates", Journal of Economic Theory, vol. 50 pp.237-264

Meese, Richard and Kenneth Rogoff, (1983) "Empirical Exchange Rate Models of the Seventies: do they fit out of sample?" International Economic Review vol. 14, pp. 3-24

Mussa, Michael, (1986), "Nominal Exchange Rate Regimes and the Behavior of Real Exchange Rates", Carnegie Rochester Conference Series on Public Policy, vol. 25 pp. 117-214

Romer, David (1986), "A Simple General Equilibrium Version of the Baumol-Tobin Model", Quarterly Journal of Economics, Vol. 101, November, Issue 4, pp. 663685 
Rotemberg, Julio, (1984), "A Monetary Equilibrium with Transactions Costs", Journal of Political Economy, vol. 92 , no. 1. pp. $40-58$

Rotemberg, Julio, (1985), "Money and the Terms of Trade", Journal of International Economics, vol. 19, Pp. 141160

Schlagenhauf, Don E. and Jeffrey M. Wrase, (1995), "Liquidity and Real Activity in a simple open economy model", Journal of Monetary Economics, June, vol. 35 , no. 3 , pp. 431-462.

Tobin, James, (1956), "The Interest Elasticity of the Transactions Demand for Cash", Review of Economics and Statistics, August, vol 38, no. 3, pp. 241-47 
Table 1.

Standard Deviation

G-7 data

annualized in percentage terms

$\Delta$ nom. exch. rate $\left(\Delta e_{t}\right) \quad 36 \%$

$\Delta$ real exch. rate $\left(\Delta x_{t}\right) \quad 37 \%$

inflation $\left(\pi_{t}\right) \quad 6 \%$

M1 growth $\left(\mu_{t}\right) \quad 14 \%$

interest rate $\left(i_{t}\right) \quad 4 \%$

inflation differential $\left(\pi_{t}^{*}-\pi_{t}\right) \quad 6 \%$

M1 growth differential $\left(\mu_{t}^{*}-\mu_{t}\right) \quad 16 \%$

interest rate differential $\left(i_{t-1}^{*}-i_{t-1}\right) \quad 4 \%$

\author{
Correlations \\ $\left(\Delta e_{t}, \Delta x_{t}\right) \quad\left(i_{t}, \pi_{t}\right)$ \\ $0.98 \quad 0.44$
}


Notation: $e_{t}-\log$ nominal exchange rate with US dollar, $\Delta e_{t}-$ First Difference of log nominal exchange rate from $t-1$ to $t, x_{t}-\log$ real exchange rate measured with $C P I$, $\Delta x_{t}-$ First Difference of log real exchange rate from $t-1$ to $t, \pi_{t}-$ First difference of the $\log$ of the price level from $t-1$ to $t$, measured by the $C P I, \mu_{t}-$ First difference of the $\log$ of the Money Supply level from $t-1$ to $t$, measured by $M 1$, $\pi_{t}^{*}-\pi_{t}$-Foreign-US inflation differential, $\mu_{t}^{*}-\mu_{t}$-ForeignUS money growth differential, $i_{t}-$ Eurocurrency one month interest rate, $i_{t-1}^{*}-i_{t-1}-$ Foreign-US interest rate differential.

Data are monthly. All statistics are averages of the corresponding statistics computed for G7 bilateral exchange rates and differentials with US. The data is for the period Jan 1973 to Dec 1994.

Sources: (i) IFS, CD Nov. 95 for CPI and Money (M1), M1 for UK was ommitted given the missing values at the end of the sample and M1 for France was reconstructed using the percentage change series from the IFS, (ii) M1 for US is from the Federal Reserve Bank of St Louis, (iii) interest rates and exchange rates are from the Harris Bank Review as compiled by Richard Levich at NYU and generously provided to us by Chris Telmer at Carnegie Mellon. 
Table 2.

Autocorrelations

\begin{tabular}{cccccc}
\multicolumn{7}{c}{ G-7 data } \\
series & $\rho_{1}$ & $\rho_{3}$ & $\rho_{6}$ & $\rho_{12}$ & $\rho_{24}$ \\
$e_{t}$ & 0.99 & 0.97 & 0.93 & 0.84 & 0.64 \\
$x_{t}$ & 0.98 & 0.94 & 0.86 & 0.72 & 0.40 \\
$\pi_{t}$ & 0.65 & 0.49 & 0.40 & 0.50 & 0.26 \\
$\mu_{t}$ & 0.40 & 0.22 & 0.20 & -0.07 & -0.13 \\
$i_{t}$ & 0.96 & 0.87 & 0.79 & 0.68 & 0.34 \\
$\pi_{t}^{*}-\pi_{t}$ & 0.32 & 0.15 & 0.18 & 0.39 & 0.31 \\
$\mu_{t}^{*}-\mu_{t}$ & -0.18 & 0.10 & 0.33 & 0.78 & 0.71 \\
$i_{t-1}^{*}-i_{t-1}$ & 0.80 & 0.59 & 0.41 & 0.29 & 0.12
\end{tabular}

Definitions and Sources are in notes to table 1. 
Table 3.

Standard Deviation

Model

annualized in percentage terms

$\Delta$ nom. exch. rate $\left(\Delta e_{t}\right) \quad 37 \%$

$\Delta$ real exch. rate $\left(\Delta x_{t}\right) \quad 37 \%$

inflation $\left(\pi_{t}\right) \quad 6 \%$

M1 growth $\left(\mu_{t}\right) \quad 6 \%$

interest rate $\left(i_{t}\right) \quad 2 \%$

inflation differential $\left(\pi_{t}^{*}-\pi_{t}\right) \quad 6 \%$

M1 growth differential $\left(\mu_{t}^{*}-\mu_{t}\right) \quad 6 \%$

interest rate differential $\left(i_{t-1}^{*}-i_{t-1}\right) \quad 2 \%$

Correlations

$\left(\Delta e_{t}, \Delta x_{t}\right) \quad\left(i_{t}, \pi_{t}\right)$

$\begin{array}{ll}0.99 & 0.99\end{array}$ 
Table 4.

Autocorrelations

\begin{tabular}{cccccc}
\multicolumn{7}{c}{$\rho_{k}-k t h$ order autocorrelation } \\
series & $\rho_{1}$ & $\rho_{3}$ & $\rho_{6}$ & $\rho_{12}$ & $\rho_{24}$ \\
$e_{t}$ & 1.0 & 1.0 & 1.0 & 1.0 & 0.99 \\
$x_{t}$ & 0.98 & 0.95 & 0.90 & 0.80 & 0.65 \\
$\pi_{t}$ & 0.98 & 0.93 & 0.87 & 0.76 & 0.59 \\
$\mu_{t}$ & 0.98 & 0.93 & 0.87 & 0.76 & 0.59 \\
$i_{t}$ & 0.98 & 0.93 & 0.85 & 0.74 & 0.56 \\
$\pi_{t}^{*}-\pi_{t}$ & 0.98 & 0.94 & 0.89 & 0.79 & 0.63 \\
$\mu_{t}^{*}-\mu_{t}$ & 0.98 & 0.94 & 0.89 & 0.79 & 0.63 \\
$i_{t-1}^{*}-i_{t-1}$ & 0.98 & 0.94 & 0.87 & 0.75 & 0.57
\end{tabular}

Statistics in both tables computed from 10,000 period simulation

using the parameter values reported in section 5 . 